\title{
Восстановление формы датчика изгибных деформаций на основе ВБР записанных в многосердцевинном волоконном световоде
}

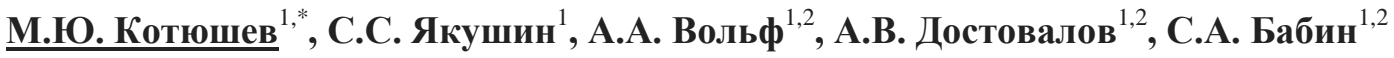 \\ ${ }^{1}$ Новосибирский государственный университет \\ ${ }^{2}$ Институт автоматики и электрометрии СО РАН \\ "E-mail: $\underline{\text { mkotyushev@gmail.com }}$
}

DOI:10.31868/RFL2018.100-101

Техническое развитие в области создания многосердцевинного оптического волокна, а также в области записи волоконных брэгговских решеток (ВБР) в последние годы позволило датчикам на основе этих технологий обрести широкое применение. Такие датчики позволяют измерять различные физические параметры волокна, такие как изгиб [1] и кручение [2], и обладают рядом преимуществ по сравнению с датчиками на электронных приборах, например, устойчивость к ЭМ- излучению и высокой температуре [3]. Это позволяет им находить применение в таких прикладных областях, как медицина, нефтедобыча, авиастроение и строительство.

В ходе данной работы была разработана и протестирована теоретическая модель распределенного датчика изгибных деформаций на основе массива ВБР, записанных в многосердцевинном волоконном световоде. Модель позволяет восстанавливать форму датчика путем анализа смещений значений резонансных длин волн ВБР относительно положения равновесия.

Для верификации разработанной модели были проведены эксперименты по восстановлению формы участка изогнутой тефлоновой трубки путем протяжки через него датчика изгибов, состоящего из массива ВБР, записанных при помощи технологии фемтосекундной записи [4]. Известная форма участка трубки сравнивалась с формой, полученной в ходе эксперимента, вычислялось абсолютное отклонение соответствующих точек двух кривых:

$$
\Delta S=\left|\vec{r}_{\text {теор }}(l)-\vec{r}_{\text {эксп }}(l)\right|
$$

где $l-$ координата вдоль теоретической кривой, $\vec{r}_{\text {теор }}$ и $\vec{r}_{\text {эксп }}-$ точки соответствующих кривых. На рис. 1 приведено сравнение теоретической и экспериментальной кривой, на рис. 2 приведена метрика $\Delta S$ данного эксперимента. 


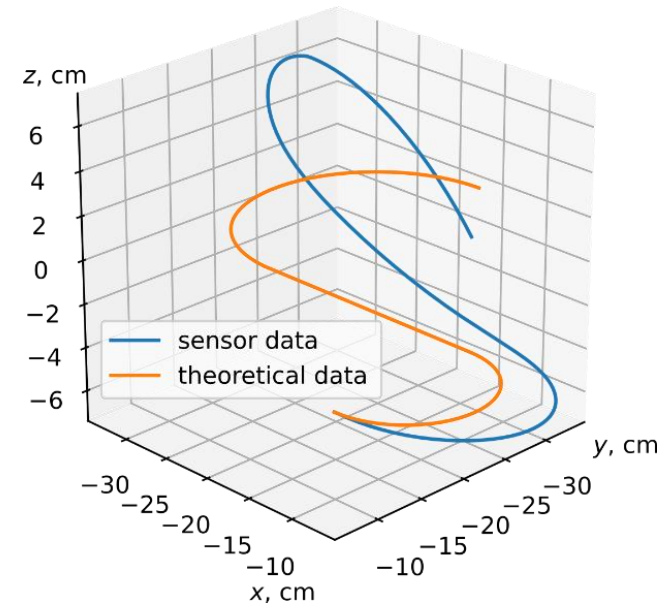

Рис.1. Сравнение экспериментальной и теоретической кривой.

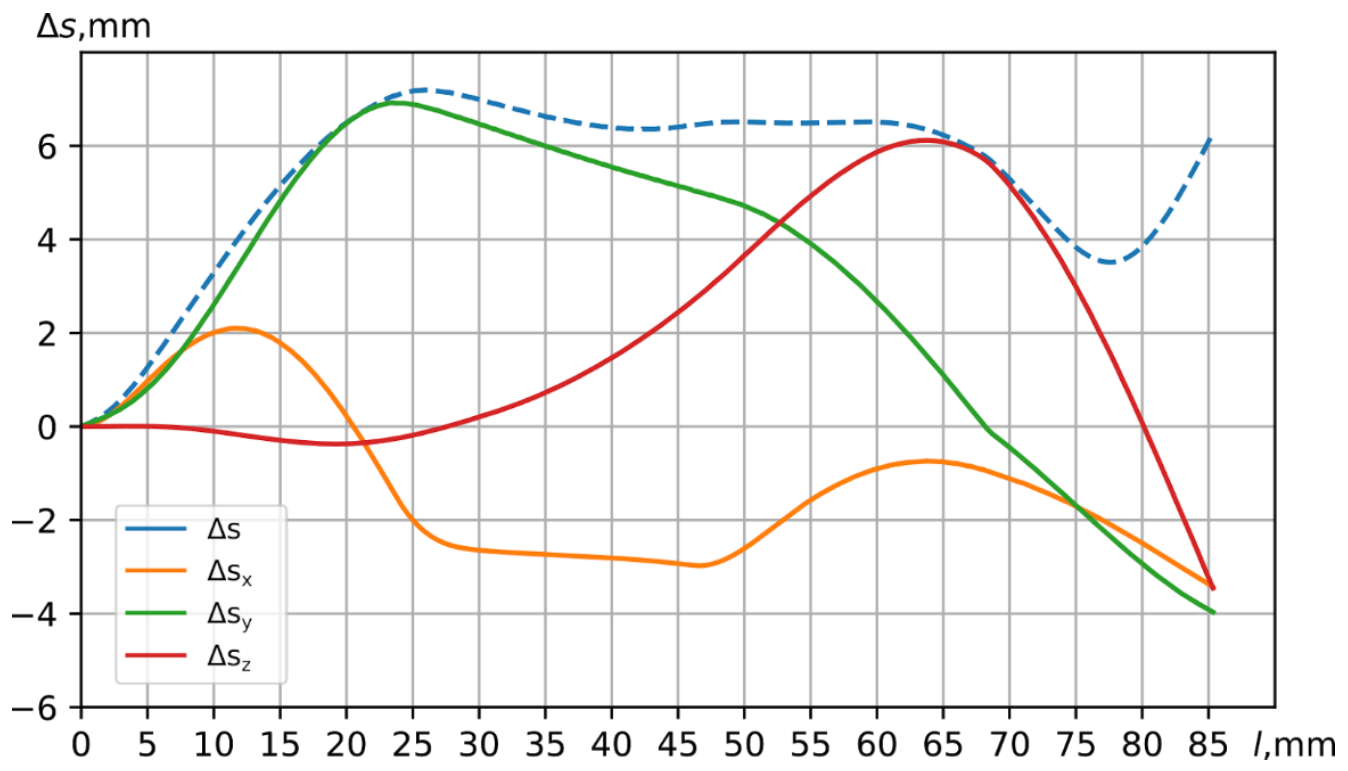

Рис. 2. Метрика сравнения $\Delta S$ экспериментальной и теоретической кривых.

В результате экспериментов было получено максимальное отклонение между теоретической и экспериментально восстановленной кривой в 23.39 мм.

Работа выполнена при поддержки гранта РНФ (18-72-00139)

\section{Литература}

[1] Moore Jason P, Rogge Matthew D, Optics Express 20, 2967 (2012)

[2] Budinski V, Donlagic D., Sensors 3, 443 (2017)

[3] Я. Буймистрюк Г., Control Engineering 3, 34-40 (2013)

[4] Thomas J., Laser \& Photonics Reviews 6, 709-723 (2012) 